Article

\title{
Self-Replication of Prion Protein Fragment 89-230 Amyloid Fibrils Accelerated by Prion Protein Fragment 107-143 Aggregates
}

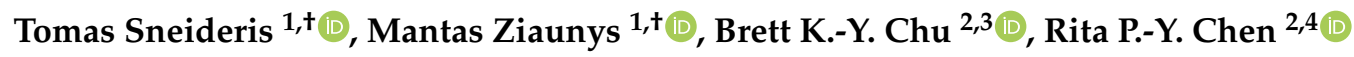 \\ and Vytautas Smirnovas $1, *$ (D) \\ 1 Institute of Biothechnology, Life Sciences Center, Vilnius University, LT-10257 Vilnius, Lithuania; \\ sneideris.t@gmail.com (T.S.); mantas.ziaunys@gmail.com (M.Z.) \\ 2 Institute of Biological Chemistry, Academia Sinica, Taipei 115, Taiwan; brettchu007@gmail.com (B.K.-Y.C.); \\ pyc@gate.sinica.edu.tw (R.P.-Y.C.) \\ 3 Department of Chemistry, National Taiwan University, Taipei 106, Taiwan \\ 4 Institute of Biochemical Sciences, National Taiwan University, Taipei 106, Taiwan \\ * Correspondence: vytautas.smirnovas@bti.vu.lt \\ + These authors contributed equally to this work.
}

Received: 21 August 2020; Accepted: 3 October 2020; Published: 8 October 2020

\begin{abstract}
Prion protein amyloid aggregates are associated with infectious neurodegenerative diseases, known as transmissible spongiform encephalopathies. Self-replication of amyloid structures by refolding of native protein molecules is the probable mechanism of disease transmission. Amyloid fibril formation and self-replication can be affected by many different factors, including other amyloid proteins and peptides. Mouse prion protein fragments 107-143 $(\operatorname{PrP}(107-143))$ and $89-230$ $(\operatorname{PrP}(89-230))$ can form amyloid fibrils. $\beta$-sheet core in $\operatorname{PrP}(89-230)$ amyloid fibrils is limited to residues $\sim 160-220$ with unstructured $\mathrm{N}$-terminus. We employed chemical kinetics tools, atomic force microscopy and Fourier-transform infrared spectroscopy, to investigate the effects of mouse prion protein fragment 107-143 fibrils on the aggregation of $\operatorname{PrP}(89-230)$. The data suggest that amyloid aggregates of a short prion-derived peptide are not able to seed $\operatorname{PrP}(89-230)$ aggregation; however, they accelerate the self-replication of $\operatorname{PrP}(89-230)$ amyloid fibrils. We conclude that $\operatorname{PrP}(107-143)$ fibrils could facilitate the self-replication of $\operatorname{PrP}(89-230)$ amyloid fibrils in several possible ways, and that this process deserves more attention as it may play an important role in amyloid propagation.
\end{abstract}

Keywords: amyloid; prion; aggregation; self-replication

\section{Introduction}

Several neurodegenerative human health disorders, such as Alzheimer's disease (AD) [1], Parkinson's disease (PD) [2], as well as prion diseases [3] are all closely linked to a process, where particular proteins fail to maintain their native conformational state and form fibrillar amyloid aggregates possessing a cross- $\beta$ structure. It is believed that the latter structure arises from arrays of $\beta$-sheets running parallel to the long axis of the fibril, while $\beta$-strands in an individual sheet are arranged perpendicularly to the fibril's axis $[4,5]$.

Understanding the process of such aggregate formation is of utmost importance, since amyloid-related disorders are becoming some of the most common medical conditions in the aging society [6], with more than 50 million people worldwide afflicted by AD and PD [1,2,7]. Currently, there are no cures or disease-modifying drugs available for most of these disorders, and even compounds that show promising results in vitro experience very high failure rates during clinical trials $[4,8-10]$. Analysis of such failures revealed that the main factors preventing successful 
development of effective anti-amyloid drugs are the relatively poor understanding of amyloid aggregation mechanisms; the lack of knowledge of the specific species and aggregation step(s) that may be affected by the molecule in question; the lack of methods to monitor the aggregation reaction in a reliable manner $[4,11]$.

Prion diseases stand out among other amyloid-related disorders due to the possible transmission between individuals and, in some cases, even between species [11]. The ability of protein amyloid aggregates to self-replicate by recruiting and refolding native protein molecules is one of the driving forces for spreading the disease [11]. The recent decade came up with many studies shedding light on the molecular-level events underlying amyloid formation. Currently, there are two defined events related with amyloid fibril self-replication: fibril elongation and fibril surface-catalyzed nucleation (often referred to as secondary nucleation) [4,12-15]. Fibril elongation is the main event that contributes to the growth of aggregate mass via the addition of individual monomers to nuclei/fibril ends, whereas secondary nucleation facilitates the proliferation of amyloid aggregates through the fibril-surface-induced formation of new growth competent nuclei. Elongating fibrils usually replicate the structure of the initial seed (with only a couple of exceptions of possible conformational switching reported $[16,17])$; however, there is increasing evidence suggesting that the structure of amyloid fibrils replicated via secondary nucleation route is dependent on the environment rather than on the template of seeds [18-21].

The structure of recombinant prion protein $(\mathrm{rPrP})$ amyloid fibrils was extensively studied by different techniques all giving similar conclusions - parallel in-register $\beta$-sheet in the C-terminal region (starting from residues 160-170, up to residues 220-225) and a disordered $\mathrm{N}$-terminus [22-25]. However, such amyloid fibrils were not infective in vivo. Studies of H/D exchange on brain-derived pathogenic prion isoform $\left(\mathrm{PrP}^{S c}\right)$ showed similar highly packed structure as in case of $\mathrm{rPrP}$ amyloid-like fibrils but in a much longer region (entire 90-230 region) [26]. This suggests that the structure of rPrP amyloid-like fibrils may be similar to the one of brain-derived $\operatorname{PrP}^{S c}$, however, with a substantially shorter $\beta$-sheet core region. Recently it was demonstrated that amyloid-like fibrils generated from $\mathrm{N}$-terminal $\operatorname{PrP}$ fragment 23-144 can be infectious in vivo [27]. These fibrils contain a parallel in-register $\beta$-sheet core in the region between $\sim 110-140$ [28], suggesting a particular importance of this region for prion infectivity. Another study showed that synthetic mouse prion protein fragment consisting of 107-143 residues (PrP(107-143)) can form amyloid fibrils, which were found to catalyze fibrillization of full-length mouse prion protein $(\operatorname{PrP}(23-230))$ [29]. We decided to study the mechanism of the $\operatorname{PrP}(107-143)$-fibril-induced aggregation of mouse prion protein C-terminal fragment 89-230 $(\operatorname{PrP}(89-230))$ expecting the reaction to proceed via one of the three possible ways. First, $\operatorname{PrP}(107-143)$ fibrils may elongate by self-replicating their structure. Second, the $\operatorname{PrP}(107-143)$ fibrils could start to elongate, however, upon recruiting longer proteins the $\beta$-sheet core would extend towards C-terminus within residues $\sim 107-225$. Finally, the $\operatorname{PrP}(107-143)$ fibrils may be incapable of elongating; however, they could accelerate $\operatorname{PrP}(89-230)$ fibril formation without self-replication of their structure via heterogeneous fibril-surface-induced nucleation. Surprisingly, it seems that none of the above happens and $\operatorname{PrP}(107-143)$ fibrils are unable to initiate the de novo aggregation reaction of $\operatorname{PrP}(89-230)$; however, in combination with $\operatorname{PrP}(89-230)$ fibrils, a synergistic effect, resulting in enhanced seed-induced $\operatorname{Pr} P(89-230)$ aggregation reaction, can be observed.

\section{Results}

First, we generated $\operatorname{PrP}(89-230)$ fibrils (Appendix A; Figure A1a) and $\operatorname{Pr} \mathrm{P}(107-143)$-fibril-induced $\operatorname{PrP}(89-230)$ fibrils (Appendix A; Figure A1b) by continuous agitation of $\operatorname{PrP}(89-230)$ monomer without and with $\operatorname{PrP}(107-143)$ fibrils, respectively, at $37^{\circ} \mathrm{C}$ in $1 \times \mathrm{PBS}(\mathrm{pH} 7.4)$ solution containing $3 \mathrm{M}$ Urea and $1 \mathrm{M} \mathrm{GuHCl}$; as described previously [29], and determined their secondary structure profiles using FTIR spectroscopy. The FTIR spectra of spontaneously formed $\operatorname{PrP}(89-230)$ fibrils and the $\operatorname{PrP}(107-143)$-fibril-induced $\operatorname{PrP}(89-230)$ fibrils were almost identical (Appendix A; Figure A1c). Moreover, PK-digestion assay revealed that there are no evident variations in the size of the PK-resistant 
core between $\operatorname{PrP}(89-230)$ fibrils and $\operatorname{PrP}(107-143)$-fibril-induced $\operatorname{PrP}(89-230)$ fibrils (Appendix A; Figure A1d). The results suggest that $\operatorname{PrP}(107-143)$ fibrils can not self-propagate their structure. In the aforementioned study [29], $\operatorname{PrP}(107-143)$-fibril-induced aggregation reaction was performed under vigorous agitation conditions. It is known that mechanical agitation induces the fragmentation of existent fibrils and facilitates the nucleation step of amyloid fibril formation as well as the detachment of species from the air-water or solid-water interface, where proteins have a strong tendency to accumulate and where, in many cases, the nucleation step is likely to occur [10,15,30-33]. Therefore, agitation could favor nucleation, and hence the spontaneous formation of $\operatorname{PrP}(89-230)$ fibrils in our sample. In order to minimize possible events of nucleation and to favor fibril elongation, the $\operatorname{PrP}(107-143)$-fibril-induced aggregation reaction was performed under quiescent conditions. Since, the aggregation reaction did not occur within reasonable experimental time (Appendix A Figure A2), the experimental conditions were modified to obtain rapid fibril elongation kinetics (by increasing temperature to $60^{\circ} \mathrm{C}$ and decreasing denaturant concentration to $0.5 \mathrm{M}$ of $\mathrm{GuHCl}$ ) [34].

\subsection{Aggregation Kinetics}

Under quiescent conditions, in the absence of any preformed aggregates or in the presence of $10 \%$ (hereafter, percentage of aggregates is relative to total protein weight in solution) of $\operatorname{PrP}(107-143)$ fibrils, aggregation of monomeric $\operatorname{PrP}(89-230)$ did not occur within the experimental time (Figure 1a,b). $\operatorname{PrP}(89-230)$ aggregation reaction, induced by the addition of $\operatorname{PrP}(89-230)$ fibrils, shows a typical fibril-concentration-dependent change in the lag phase (Figure 1a,c), yielding sigmoidal shaped curves. If we compare the lag time $\left(t_{\text {lag }}\right)$ values of seed-induced aggregation reaction performed in the absence and presence of $10 \%$ of $\operatorname{PrP}(107-143)$ fibrils, it appears that the lag phase in the presence of $\operatorname{PrP}(107-143)$ aggregates is shorter as if there was a higher concentration of $\operatorname{PrP}(89-230)$ seed present (Figure 1c). This divergence between $t_{\text {lag }}$ values becomes more evident as the concentration of $\operatorname{PrP}(89-230)$ seeds increases (Figure 1d). $\operatorname{PrP}(107-143)$ fibrils shorten the lag phase of the $\operatorname{PrP}(89-230)$ seed-induced aggregation reaction in a concentration-dependent manner (Figure 1e,f).

Additionally, we performed experiments where we introduced $\operatorname{PrP}(107-143)$ fibrils at different time-points of $\operatorname{PrP}(89-230)$ self-replication reaction (Appendix A; Figure A3). The introduction of $\operatorname{PrP}(107-143)$ fibrils at any time-point resulted in the shortening of $t_{\text {lag; }}$, however, the strongest effect on $t_{\text {lag }}$ was most prominent when the $\operatorname{PrP}(107-143)$ fibrils were introduced at the very beginning of the reaction (Figure A3). Similarly, the introduction of the $\operatorname{PrP}(89-230)$ seed at any time-point of the aggregation reaction of monomeric $\operatorname{PrP}(89-230)$ performed in the presence of $\operatorname{PrP}(107-143)$ fibrils resulted in the shortening of $t_{\text {lag }}$ of $\operatorname{PrP}(89-230)$ aggregation reaction, with the strongest effect evident upon introduction of $\operatorname{PrP}(89-230)$ fibrils at the early stages of the aggregation reaction (Figure A4). Similarly, as described previously, $\operatorname{PrP}(107-143)$ fibrils alone had no evident effect on the aggregation reaction of monomeric $\operatorname{PrP}(89-230)$ within the experimental time.

\subsection{Morphology}

Sample analysis via atomic force microscopy (AFM) revealed that, while the $\operatorname{PrP}(107-143)$ does spontaneously form fibrils itself (Figure 2a), it seems that the $\operatorname{PrP}(107-143)$ fibrils do not induce the aggregation of monomeric $\operatorname{PrP}(89-230)$, as the fibrils observed after $1000 \mathrm{~min}$ of incubation (Figure 2e) are of similar length ( 200-600 nm) as the seed (Figure 2c). In the case when the $\operatorname{PrP}(89-230)$ fibrils (Figure 2d) were used as a seed, both in the presence or absence of $\operatorname{Pr} P(107-143)$ aggregates, the resulting fibrils (Figure 2f,g) appear to be of similar length (several hundred of nm to few $\mu \mathrm{m}$ ) to the spontaneously formed $\operatorname{PrP}(89-230)$ fibrils (Figure 2b). Please, also see Appendix A; Figure A5. 

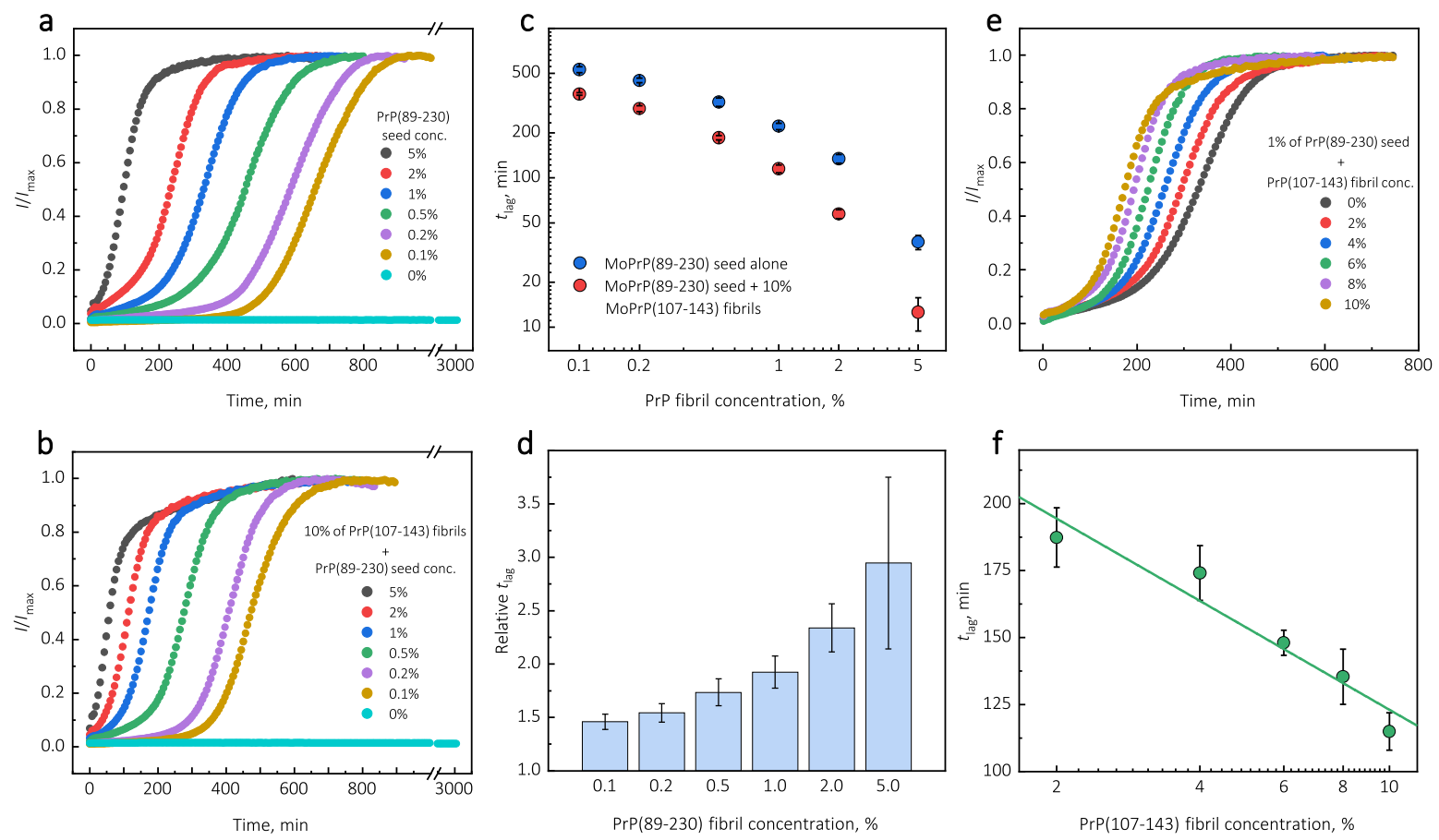

Figure 1. Representative curves of PrP-seed-induced aggregation reaction kinetics performed in the absence (a) or presence (b) of $\operatorname{PrP}(107-143)$ fibrils. Logarithmic plot of $t_{\text {lag }}$ values of seed-induced aggregation reaction performed in the absence and presence of $10 \%$ of $\operatorname{PrP}(107-143)$ fibrils (c). Relative $t_{\text {lag }}$ values (ratio between $t_{\text {lag }}$ in the absence and presence of $10 \%$ peptide fibrils) (d). Dependence of $\operatorname{PrP}(89-230)$-seed-induced aggregation reaction kinetics on the initial concentration of $\operatorname{PrP}(107-143)$ fibrils $(\mathbf{e}, \mathbf{f})$. Error bars are standard deviations $(n=9)$.
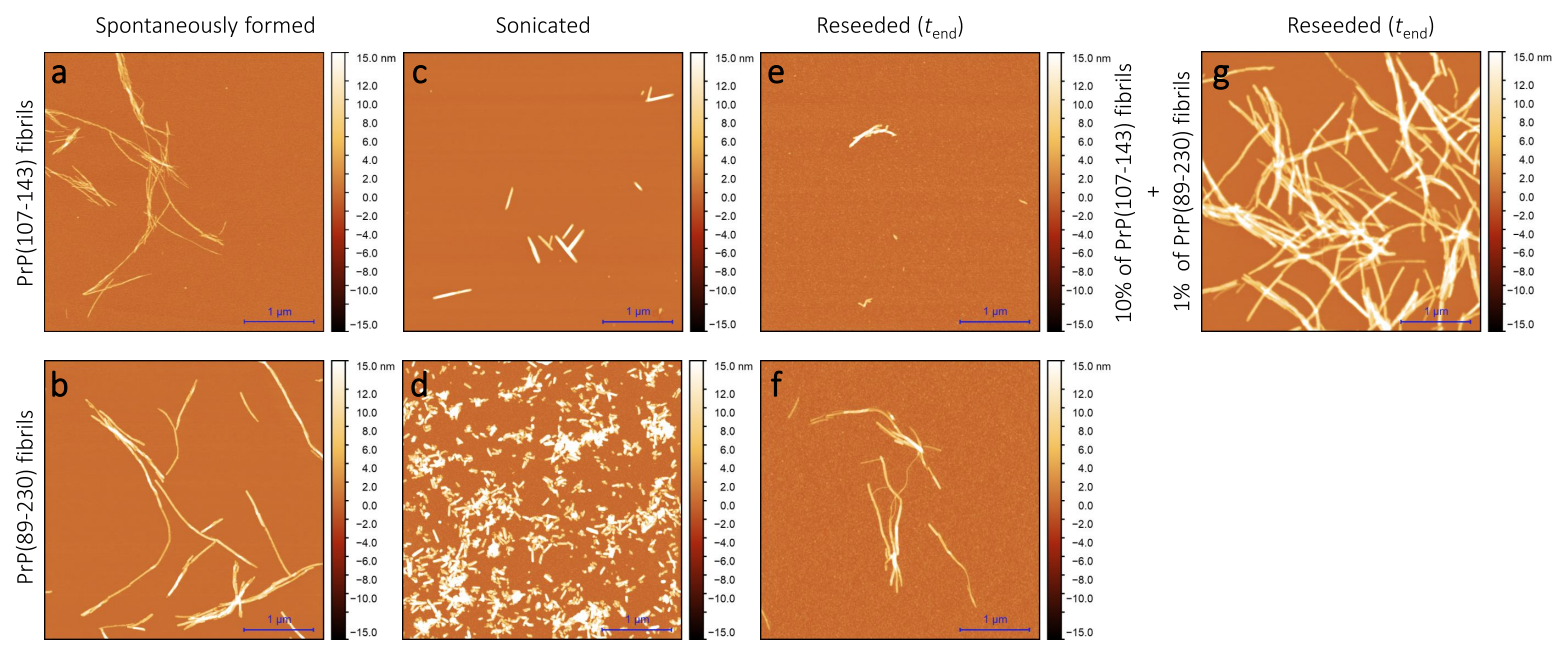

Figure 2. AFM images of $\operatorname{PrP}(107-143)$ and $\operatorname{PrP}(89-230)$ aggregates. Images of the spontaneously formed $\operatorname{PrP}(107-143)$ (a) and $\operatorname{PrP}(89-230)$ (b) aggregates. Images of sonicated $\operatorname{PrP}(107-143)$ (c) and $\operatorname{PrP}(89-230)$ (d) aggregates. Images of aggregates formed during $\operatorname{PrP}(107-143)$-fibril-induced (e) or $\operatorname{PrP}(89-230)$-seed-induced (f) aggregation reaction. Images of aggregates formed in the presence of both $\operatorname{PrP}(107-143)$-fibrils and $\operatorname{PrP}(89-230)$-seed (g).

\subsection{Secondary Structure}

The Fourier-transform infrared (FTIR) spectroscopy spectra of all examined $\operatorname{PrP}(89-230)$ fibril samples possess similar structural profiles in the amide I/I' region. $\operatorname{PrP}(89-230)$ fibril spectra exhibit maxima at $\sim 1627 \mathrm{~cm}^{-1}$ (with the main minima of the second derivative at $\sim 1622 \mathrm{~cm}^{-1}$ and a weaker one at $\sim 1628 \mathrm{~cm}^{-1}$ ) and a shoulder which is reflected by the minimum of the second derivative at 
$\sim 1662 \mathrm{~cm}^{-1}$ (Figure 3). The spectral profile of spontaneously formed $\operatorname{PrP}(107-143)$ fibrils is slightly different from the rest. The FTIR spectrum of latter fibrils exhibits a maximum at $\sim 1626 \mathrm{~cm}^{-1}$ (with the single minimum of the second derivative at $\left.\sim 1626 \mathrm{~cm}^{-1}\right)$. The results suggest that $\operatorname{PrP}(107-143)$ fibrils are unable to self-propagate by imprinting their structural template on $\operatorname{Pr} \mathrm{P}(89-230)$ monomers.

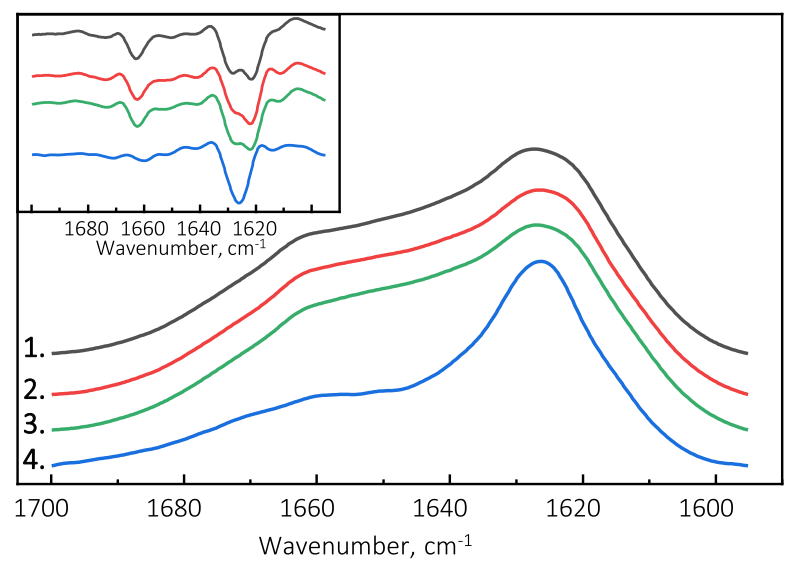

Figure 3. Absorbance and second derivative (inset) FTIR spectra of $\operatorname{PrP}(89-230)$ and $\operatorname{PrP}(107-143)$ fibrils. 1.-Spontaneously formed $\operatorname{PrP}(89-230)$ fibrils. 2.-Fibrils formed in the presence of $1 \%$ of $\operatorname{PrP}(89-230)$ fibrils. 3.-Fibrils formed in the presence of $10 \%$ of $\operatorname{PrP}(107-143)$ fibrils and $1 \%$ of $\operatorname{PrP}(89-230)$ fibrils. 4.- Spontaneously formed $\operatorname{PrP}(107-143)$ fibrils.

\section{Discussion}

Surprisingly, the addition of high amounts (10\%) of $\operatorname{PrP}(107-143)$ fibrils into $\operatorname{PrP}(89-230)$ monomer solution had no effect on aggregation kinetics within the experimental time, whereas addition of even very low amounts $(0.1 \%)$ of $\operatorname{PrP}(89-230)$ fibrils resulted in a substantial acceleration of aggregation reaction (Figure 1a,b). This suggests that heterogeneous seeding is extremely inefficient in this case. Interestingly, when both types of aggregates were co-added into $\operatorname{PrP}(89-230)$ monomer solution, the aggregation promoting effect was stronger than in case of the $\operatorname{Pr} P(89-230)$-seed alone. This raises the question: What is the origin of such an effect? From the $t_{\text {lag }}$ plot, it is evident that in the presence of $10 \%$ of $\operatorname{PrP}(107-143)$ fibrils $t_{\text {lag }}$ values of $\operatorname{PrP}(89-230)$ seed-induced aggregation reaction are lower as if the initial concentration of preformed $\operatorname{Pr} \mathrm{P}(89-230)$ aggregates was higher (Figure 1c and Appendix A Figure A6). For instance, in the presence of $10 \%$ of $\operatorname{PrP}(107-143)$ fibrils and $2 \%$ of $\operatorname{PrP}(89-230)$ seed, the $t_{\text {lag }}$ value is $\sim 2.3$ times lower, when compared to control, as if the initial concentration of $\operatorname{PrP}(89-230)$ seed was $\sim 3.9 \%$ (dashed lines in Appendix A Figure A6). This suggests that $10 \%$ of $\operatorname{PrP}(107-143$ ) fibrils should act as $\sim 1.9 \%$ of $\operatorname{PrP}(89-230)$ seed, which would point towards a cumulative aggregation promoting effect. If this was true, the aggregation promoting effect of $\operatorname{Pr} P(107-143)$ fibrils alone should be evident; however, it is not, suggesting that the presence of $\operatorname{PrP}(89-230)$ seed is essential for $\operatorname{PrP}(107-143)$ fibrils to have an effect on the $\operatorname{PrP}(89-230)$ aggregation reaction. This implies that the aggregation promoting effect is synergistic in origin.

As suggested by AFM images (Figure 2e), it seems that the $\operatorname{PrP}(107-143)$ fibrils are incapable of elongatingthrough recruitment of $\operatorname{PrP}(89-230)$ monomers (or the elongation rate is extremely slow). Moreover, FTIR results suggest that the presence of $\operatorname{PrP}(107-143)$ fibrils has no effect on the structural profiles of the resulting $\operatorname{PrP}(89-230)$ fibrils. Thus, suggesting that the presence of $\operatorname{PrP}(107-143)$ fibrils affect only the lag phase of the $\operatorname{PrP}(89-230)$-seed-induced aggregation reaction. The presence of monomeric $\operatorname{PrP}(107-143)$ has no effect on the aggregation kinetics of $\operatorname{PrP}(89-230)$-seed-induced aggregation reaction (Appendix A; Figure A7), meaning that the synergistic effect most likely results from the interplay between fibrils formed by $\operatorname{PrP}(107-143)$ and $\operatorname{PrP}(89-230)$.

Primary nuclei capable of seeding aggregation reaction of monomeric proteins form relatively early during the lag phase of aggregation reaction [35], and the agitation facilitates this process. Therefore, it is likely that the aggregation-promoting effect of $\operatorname{PrP}(107-143)$ fibrils observed under 
agitated conditions [29] results in fact due to the interplay between $\operatorname{PrP}(107-143)$-fibrils and the agitation-induced spontaneously formed aggregation prone PrP species.

The surface of preformed aggregates can catalyze formation of new growth-competent nuclei in three main ways. First, the protein monomers can condense on the surface of existing fibrils, which results in the increased local concentration of the protein. If the diffusion of the surface-bound protein is restricted to two, rather than three dimensions, the likelihood of possible encounters increases [31,33,36,37]. Indeed, the $\operatorname{PrP}(107-143)$ fibrils bind a small fraction of $\operatorname{PrP}(89-230)$ monomers (Appendix A; Figure A8). Therefore, it is possible that $\operatorname{Pr} \mathrm{P}(89-230)$ monomers can condense on the surface of the $\operatorname{PrP}(107-143)$ fibrils. However, $\operatorname{PrP}(107-143)$-fibrils alone do not efficiently facilitate aggregation of monomeric $\operatorname{PrP}(89-230)$, suggesting that the local concentration of $\operatorname{PrP}(107-143)$ fibril-surface-bound $\operatorname{PrP}(89-230)$ monomers is very small and hence the low probability of new growth-competent nuclei formation. This could result due to a weak interaction between $\operatorname{PrP}(89-230)$ monomers $\operatorname{PrP}(107-143)$ fibrils [37]. If the monomer-fibril interaction strength is weak, protein monomers cover only a small fraction of the fibril surface, and the monomer adsorption and oligomer/nuclei formation on the fibril surface become the rate-limiting steps of the fibril self-replication reaction [37]. Almost identical secondary structure profiles of $\operatorname{PrP}(89-230)$ fibrils and the fibrils formed in the presence of $\operatorname{PrP}(107-143)$ fibrils (Figure 3 and Appendix A Figure A1c) suggest that the rate of $\operatorname{PrP}(107-143)$ fibril self-replication reaction could be slow enough for spontaneous $\operatorname{PrP}(89-230)$ aggregation reaction to overcome it.

Second, existing aggregates can reduce the interfacial energy and lead to the formation of new nuclei. If protein monomers condense on the surface of fibrils, their contact with the solution is lower than when they are present in the bulk of the solution [33]. This way, if the interfacial energy is lower at the $\operatorname{PrP}(89-230)$ monomers- $\operatorname{Pr} P(107-143)$ fibril contact area, then the free energy barrier of nuclei formation would be reduced [31,33].

Third, the interaction of the protein with the fibril surface may alter the nucleation process. For instance, the fibril-surface-bound monomented favorablrs can be oriey for the nucleation event to occur [33]. Moreover, protein adsorption on the surface of the fibril may induce structural rearrangements that would result in the appearance of accessible protein conformations that would be too high in energy in bulk solutions [33]. This could also lower the effective energy barrier of the nucleation reaction. In our case, we could assume that $\operatorname{PrP}(107-143)$ fibril-surface-bound monomers may acquire a conformation(s), which is not suitable for the formation of aggregation-prone nuclei on the $\operatorname{PrP}(107-143)$ fibril surface, or which can not be recruited by the $\operatorname{PrP}(107-143)$ fibril ends. Such monomers, however, could detach from the fibril surface into the bulk of the solution, where they could be subsequently recruited by the $\operatorname{PrP}(89-230)$ fibrils. This would facilitate the $\operatorname{PrP}(89-230)$ fibril self-replication reaction due to a lower effective energy barrier of nucleation/elongation. Moreover, it is likely that $\operatorname{PrP}(89-230)$ affinity for the fibrils formed by $\operatorname{PrP}(89-230)$ is substantially higher that that for fibrils formed by $\operatorname{PrP}(107-143)$, which means that if the $\operatorname{PrP}(89-230)$ fibrils would come into a close proximity with the $\operatorname{PrP}(107-143)$ fibrils, they could recruit $\operatorname{PrP}(89-230)$ monomers adsorbed onto the $\operatorname{PrP}(107-143)$ fibril surface. This would again facilitate self-replication reaction due to a lower effective energy barrier of the nucleation/elongation and due to increased local concentration of $\operatorname{PrP}(89-230)$ monomers. Additional experiments, during which we introduced $\operatorname{PrP}(107-143)$ fibrils at different time-points of $\operatorname{PrP}(89-230)$ self-replication reaction (Figure A3), revealed that the $\operatorname{PrP}(107-143)$ fibrils affect mainly the nucleation process. When the $\operatorname{PrP}(107-143)$ fibrils were added at the beginning of the self-replication reaction, the $t_{\text {lag }}$ was $\sim 80 \mathrm{~min}$ shorter when compared to the $t_{\text {lag }}$ of the sample where the addition of $\operatorname{PrP}(107-143)$ fibrils was delayed by $90 \mathrm{~min}$. However, the $t_{\text {lag }}$ difference between samples where $\operatorname{PrP}(107-143)$ fibrils were introduced after 90 min and 435 min delay is small. This suggests that the nucleation enhancing effect of $\operatorname{PrP}(107-143)$ fibrils is much stronger at later stages (i.e., at $435 \mathrm{~min}$ ) of the aggregation reaction and this could be explained by the fact that the concentration of nuclei/fibril ends is much higher at this stage of the reaction. These results are in agreement with the data presented in Figure 1, where the synergistic effect of different PrP fibrils 
was most evident at the highest concentrations of $\operatorname{PrP}(89-230)$ fibrils. The opposite experiments, during which we introduced $\operatorname{PrP}(89-230)$ fibrils at different time-points of $\operatorname{PrP}(89-230)$ aggregation reaction (Figure A4) in the presence of $\operatorname{PrP}(107-143)$ fibrils were also performed. The experimentally determined $t_{\text {lag }}$ values for the samples where $\operatorname{PrP}(89-230)$ fibrils were introduced at 180 and $360 \mathrm{~min}$ are equal (within the error margin) to the sum of the $t_{\text {lag }}$ value determined for the sample where fibrils were introduced at the beginning of the reaction and the times of $\operatorname{PrP}(89-230)$ fibril introduction. This suggests that the presence of both $\operatorname{PrP}(107-143)$ and $\operatorname{PrP}(89-230)$ fibrils at the same time is important for the maximum acceleration of monomer nucleation.

In general, we can conclude that aggregates formed by $\operatorname{PrP}(107-147)$ are not able to seed aggregation reactions of monomeric $\operatorname{PrP}(89-230)$; however, they can facilitate the self-replication reaction of $\operatorname{PrP}(89-230)$ amyloid fibrils via several possible ways. A synergistic seeding effect of two different amyloid fibrils deserves more attention, as it may play an important role in amyloid propagation.

\section{Materials and Methods}

\subsection{Measurements of Aggregation Kinetics}

Mouse recombinant prion protein C-terminal fragment 89-230 ( $\operatorname{PrP}(89-230))$ was expressed in E. coli and purified according to the previously described protocol [34]. After purification, the protein was dialyzed against MilliQ water, and lyophilized. In addition to the $\operatorname{PrP}(89-230)$ sequence, the protein contains a 4-residue N-terminal extension (GSDP).

Synthetic mouse prion protein fragment 107-143 ( $\operatorname{PrP}(107-143))$ was produced as described previously [29].

To prepare $\operatorname{PrP}(89-230)$ fibrils, $5 \mathrm{mg}$ of lyophilized $\operatorname{PrP}(89-230)$ was dissolved in $1 \mathrm{~mL}$ of $50 \mathrm{mM}$ phosphate buffer ( $\mathrm{pH}$ 6) containing $0.5 \mathrm{M} \mathrm{GuHCl}$ and filtered through $0.45 \mu \mathrm{m}$ pore size syringe filter. The concentration of monomeric $\operatorname{PrP}(89-230)$ (M.W. $=16,555 \mathrm{Da}, \varepsilon_{280}=27,515 \mathrm{M}^{-1} \mathrm{~cm}^{-1}$ ) was determined by measuring UV-absorption at $280 \mathrm{~nm}$ using NanoDrop 2000 (Thermo Fisher Scientific, Wolsom, MA, USA). Subsequently, the $\operatorname{PrP}(89-230)$ solution was diluted to a final concentration of $0.5 \mathrm{mg} / \mathrm{mL}$ using $50 \mathrm{mM}$ phosphate buffer $(\mathrm{pH}$ 6) containing $0.5 \mathrm{M} \mathrm{GuHCl}$ and incubated for 1 day at $60{ }^{\circ} \mathrm{C}$ with 600 RPM shaking in a thermomixer MHR 23 (Ditabis, Pforzheim, Germany). For seeding experiments, $\operatorname{PrP}(89-230)$ fibrils were sonicated for $10 \mathrm{~min}$ on ice using Sonopuls 3100 (Bandelin, Berlin, Germany) ultrasonic homogenizer equipped with MS72 tip (using 20\% power, cycles of $30 \mathrm{~s} / 30 \mathrm{~s}$ sonication/rest, total energy applied to the sample per cycle $\sim 0.36 \mathrm{~kJ})$. Right after the treatment, $\operatorname{PrP}(89-230)$ fibrils were mixed with $0.5 \mathrm{mg} / \mathrm{mL} \operatorname{PrP}(89-230)$ solution in $0.5 \mathrm{M} \mathrm{GuHCl}$ in $50 \mathrm{mM}$ phosphate buffer, $\mathrm{pH} 6$, containing $50 \mu \mathrm{M}$ ThT.

To prepare $\operatorname{PrP}(107-143)$ fibrils, $1 \mathrm{mg}$ of synthetic $\operatorname{PrP}(107-143)$ was dissolved in $1 \mathrm{~mL}$ of MilliQ water and filtered through $0.45 \mu \mathrm{m}$ pore size syringe filter. The concentration of the $\operatorname{PrP}(107-143)$ (M.W. $=3699 \mathrm{Da}, \varepsilon_{280}=1490 \mathrm{M}^{-1} \mathrm{~cm}^{-1}$ ) was determined by measuring UV-absorption at $280 \mathrm{~nm}$ using NanoDrop 2000 (Thermo Fisher Scientific, Wolsom, MA, USA). Subsequently, the peptide solution was diluted to a final concentration of $0.5 \mathrm{mg} / \mathrm{mL}$ using MilliQ water. Then $0.5 \mathrm{mg} / \mathrm{mL}$ $\operatorname{PrP}(107-143)$ solution was mixed with $40 \mathrm{mM}$ sodium acetate, $\mathrm{pH} 3.7$, supplemented with $280 \mathrm{mM}$ $\mathrm{NaCl}$ in a $1: 1$ ratio, and incubated for 2 days at $25^{\circ} \mathrm{C}$ under quiescent conditions. Then, fibrils were centrifuged at $10,000 \times g$ for $30 \mathrm{~min}$ and re-suspended in $50 \mathrm{mM}$ phosphate buffer $(\mathrm{pH} 6)$ containing $0.5 \mathrm{M} \mathrm{GuHCl}$. The concentration of monomer remaining in the supernatant was determined by measuring UV absorption. For seeding experiments, fibrils were sonicated for $30 \mathrm{~s}$ on ice using Sonopuls 3100 (Bandelin, Berlin, Germany) ultrasonic homogenizer equipped with MS72 tip (using $20 \%$ of the power, total energy applied to the sample $\sim 0.36 \mathrm{~kJ}$ ). Right after the treatment, fibrils were mixed with $0.5 \mathrm{mg} / \mathrm{mL} \operatorname{PrP}(89-230)$ solution in $0.5 \mathrm{M} \mathrm{GuHCl}$ in $50 \mathrm{mM}$ phosphate buffer, $\mathrm{pH} 6$, containing $50 \mu \mathrm{M}$ ThT. 
For co-seeded aggregation experiments, sonicated $\operatorname{PrP}(89-230)$ and $\operatorname{PrP}(107-143)$ fibrils were co-added into $0.5 \mathrm{mg} / \mathrm{mL} \operatorname{PrP}(89-230)$ solution in $0.5 \mathrm{M} \mathrm{GuHCl}$ in $50 \mathrm{mM}$ phosphate buffer, $\mathrm{pH}$ 6, containing $50 \mu \mathrm{M}$ ThT.

Aggregation kinetics at $60{ }^{\circ} \mathrm{C}$ temperature were monitored by ThT fluorescence assay (excitation at $470 \mathrm{~nm}$, emission at $510 \mathrm{~nm}$ ) using Rotor-Gene Q (Qiagen, Hilden, Germany) real-time analyzer.

The ThT fluorescence intensity was normalized by dividing each data point by the maximum intensity of the curve. In the case of data where no change in ThT fluorescence intensity was evident, each data point was divided by the maximum intensity of the curve obtained in the presence of $5 \%$ of PrP seed. The aggregation lag time $\left(\mathrm{t}_{\text {lag }}\right)$ values were calculated by applying a linear fit to the data points ranging from $40 \%$ to $60 \%$ of normalized intensity values and finding $x$ value at $y=0$. We employed AmyloFit software [13] to analyze the kinetic data of the $\operatorname{PrP}(89-230)$ self-replication reaction in the absence and the presence of $\operatorname{PrP}(107-143)$ fibrils, but none of the available models gave an acceptable fit. The best fit was obtained using the Saturating Elongation and Secondary Nucleation model (Appendix A; Figure A9).

\subsection{Atomic Force Microscopy (AFM)}

AFM measurements were performed as described previously [38]. During the AFM imaging, to avoid large imaging force and keep consistency within independent samples, the constant regime of phase change not exceeding $\Delta 20^{\circ}$ was maintained [39]. AFM images were flattened using Gwyddion software (Czech metrology institute, Jihlava, Czechia) as described previously [39].

\subsection{Fourier-Transform Infrared (FTIR) Spectroscopy}

FTIR measurements were performed as described previously [10].

Author Contributions: Conceptualization, T.S., M.Z., R.P.-Y.C. and V.S.; investigation, T.S., M.Z. and B.K.-Y.C.; resources, R.P.Y.Y. and V.S.; writing-original draft preparation, T.S. and V.S.; writing-review and editing, T.S., M.Z., B.K.-Y.C., R.P.-Y.C. and V.S.; supervision, R.P.-Y.C. and V.S.; funding acquisition, R.P.-Y.C. and V.S. All authors have read and agreed to the published version of the manuscript.

Funding: This research was funded by the grant no. TAP LLT-1/2017 from the Research Council of Lithuania.

Acknowledgments: The authors acknowledge G. Niaura from the Center of Physical Sciences and Technology for the access to FTIR.

Conflicts of Interest: The authors declare no conflict of interest. 


\section{Appendix A}

a

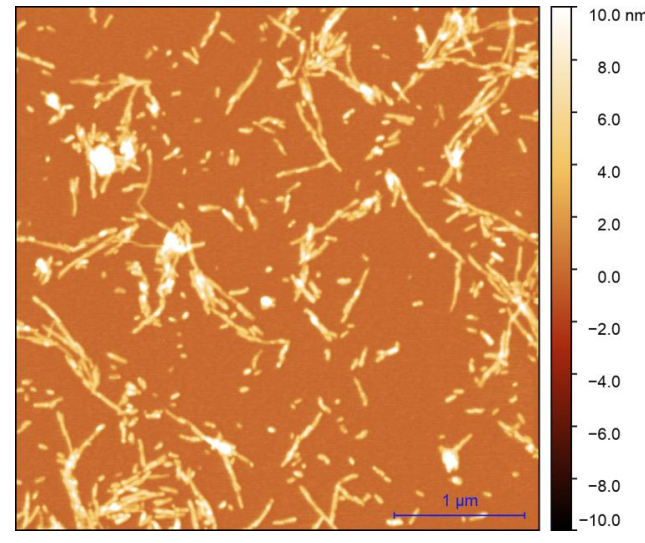

C

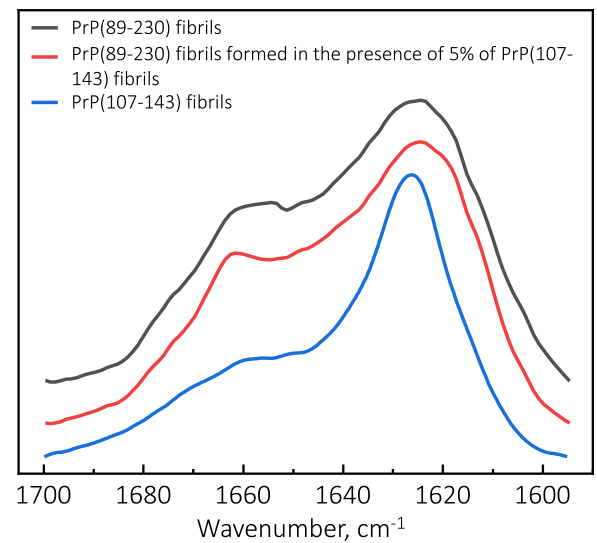

b

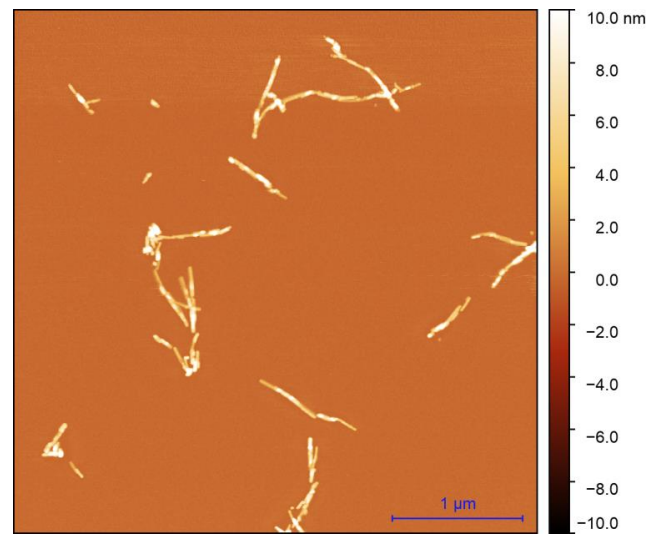

d

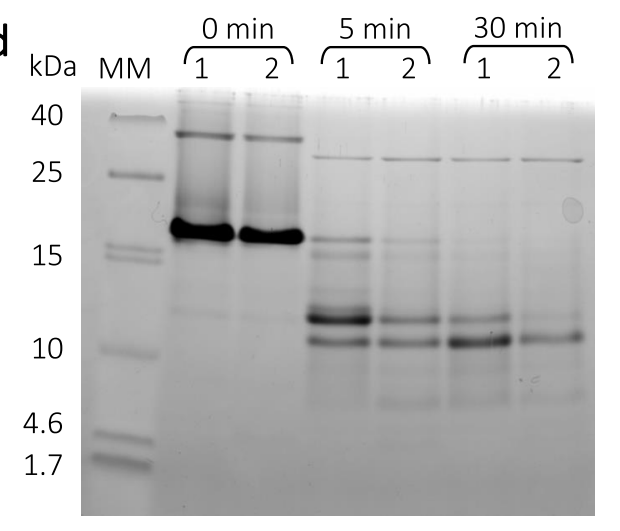

Figure A1. AFM images (a,b), FTIR spectra (c) and PK digestion SDS-PAGE (d) of PrP fibrils. (a) AFM image of $\operatorname{PrP}(89-230)$ fibrils. (b) AFM image of $\operatorname{PrP}(89-230)$ fibrils formed in the presence of $5 \%$ of $\operatorname{PrP}(107-143)$ aggregates. (c) FTIR spectra of $\operatorname{PrP}(89-230)$ fibrils formed in the absence or presence of $\operatorname{PrP}(107-143)$ fibrils, and $\operatorname{PrP}(107-143)$ fibrils alone. (d) MM-molecular weight marker; $1-\operatorname{PrP}(89-230)$ fibrils; 2- $\operatorname{PrP}(89-230)$ fibrils formed in the presence of $5 \%$ of $\operatorname{PrP}(107-143)$ aggregates; time denotes PK digestion time. For PK digestion experiments, fibril samples $(0.5 \mathrm{mg} / \mathrm{mL})$ were centrifuged at $10,000 \times g$ for $30 \mathrm{~min}$. Subsequently, fibrils were resuspended in $50 \mathrm{mM}$ Tris buffer solution $(\mathrm{pH} 8)$ and centrifuged again. Then fibrils were resuspended in $200 \mu \mathrm{L}$ of $50 \mathrm{mM}$ Tris buffer solution (pH 8) and sonicated for $30 \mathrm{~s}$ using Bandelin Sonopuls ultrasonic homogenizer equipped with a MS 72 tip (using $20 \%$ of the power, total energy applied to the sample $\sim 0.36 \mathrm{~kJ}$ ). After sonication, the fibril solution was supplemented with $2.5 \mu \mathrm{L}$ of $2 \mathrm{mg} / \mathrm{mL}$ Proteinase $\mathrm{K}$ and incubated for $0 \mathrm{~min}, 5 \mathrm{~min}$ and $30 \mathrm{~min}$ at $37^{\circ} \mathrm{C}$ with $600 \mathrm{RPM}$ agitation in a Ditabis thermomixer MHR 23. Then, $17 \mu \mathrm{L}$ of each sample was collected, supplemented with $3 \mu \mathrm{L}$ of $10 \mathrm{mM} \mathrm{PMSF}, 96 \% \mathrm{EtOH}$ and $20 \mu \mathrm{L}$ of $2 \times$ SDS-Page sample buffer containing $6 \mathrm{M}$ Urea. Samples were heated for $15 \mathrm{~min}$ at $98^{\circ} \mathrm{C}$ and subsequently analyzed via Tricine-SDS-PAGE [40]. 


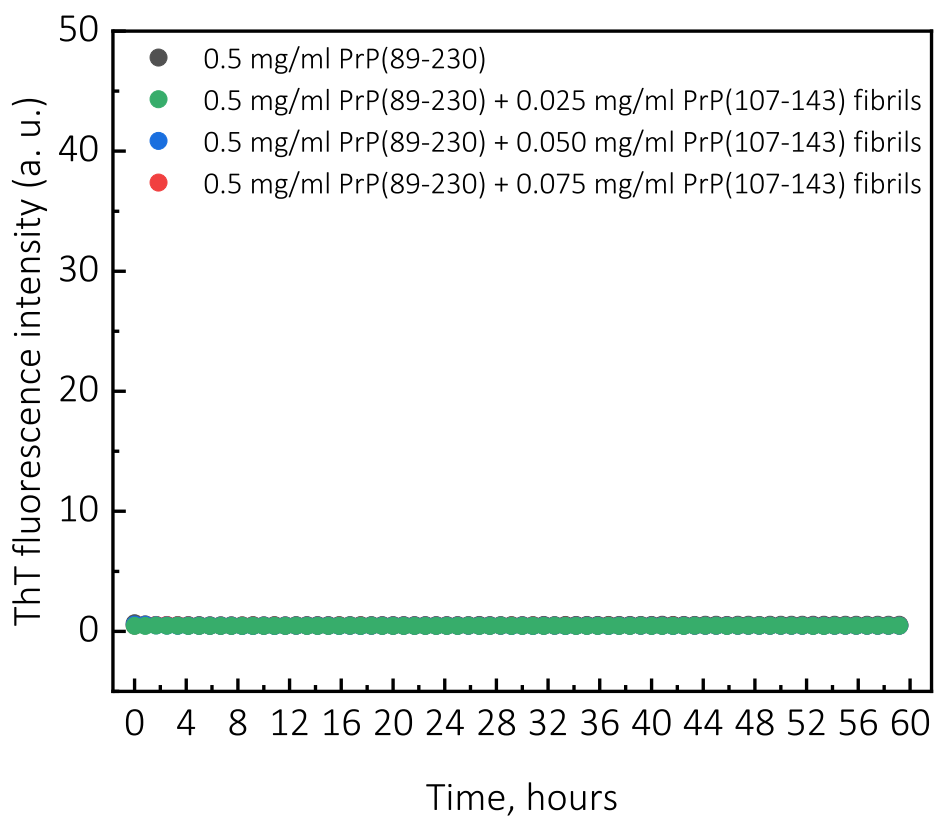

Figure A2. Representative curves of $\operatorname{PrP}(107-143)$-fibril-induced aggregation reaction kinetics monitored at $37^{\circ} \mathrm{C}$ under quiescent conditions. For aggregation experiments, solutions of $0.5 \mathrm{mg} / \mathrm{mL}$ of monomeric $\operatorname{PrP}(89-230)$ protein in $1 \mathrm{M} \mathrm{GuHCl}, 3 \mathrm{M}$ Urea, $1 \times \mathrm{PBS}$ (pH 7.4), containing $50 \mu \mathrm{M}$ ThT were supplemented with none, $0.025,0.050$, or $0.075 \mathrm{mg} / \mathrm{mL}$ of $\operatorname{PrP}(107-143)$ fibrils and incubated under quiescent conditions at $37^{\circ} \mathrm{C}$ temperature. Aggregation kinetics were monitored by ThT fluorescence assay (excitation at $470 \mathrm{~nm}$, emission at $510 \mathrm{~nm}$ ) using Qiagen Rotor-Gene Q real-time analyzer.

- $0.001 \mathrm{mg} / \mathrm{ml} \operatorname{PrP}(89-230)$ seed

- $0.001 \mathrm{mg} / \mathrm{ml} \operatorname{PrP}(89-230)$ seed $+0.05 \mathrm{mg} / \mathrm{ml} \operatorname{PrP}(107-143)$ fibrils (added at $0 \mathrm{~min}$ )

- $0.001 \mathrm{mg} / \mathrm{ml} \operatorname{PrP}(89-230)$ seed $+0.05 \mathrm{mg} / \mathrm{ml} \operatorname{PrP}(107-143)$ fibrils (added at $90 \mathrm{~min}$ )

$0.001 \mathrm{mg} / \mathrm{ml} \operatorname{PrP}(89-230)$ seed $+0.05 \mathrm{mg} / \mathrm{ml} \operatorname{PrP}(107-143)$ fibrils (added at $435 \mathrm{~min}$ )

a

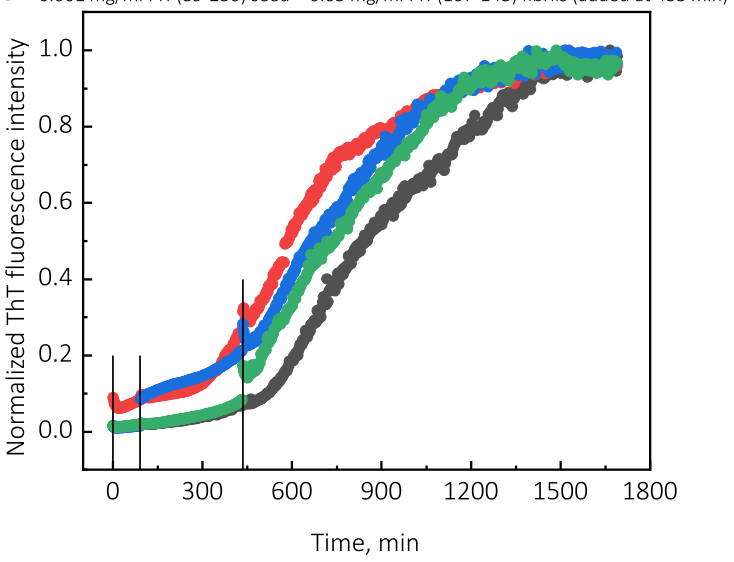

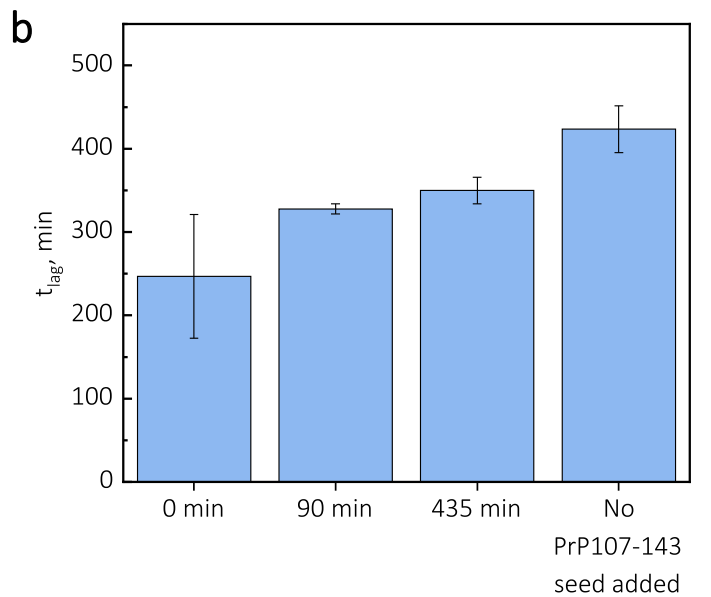

Figure A3. Average kinetic curves (a) and $t_{\text {lag }}$ values (b) of $\operatorname{PrP}(89-230)$ self-replication reaction performed with introduction of $\operatorname{PrP}(107-143)$ seed at different time-points of the reaction. Then, $10 \mu \mathrm{L}$ of $0.5 \mathrm{mg} / \mathrm{mL} \operatorname{PrP}(107-143)$ fibrils were added to $100 \mu \mathrm{L}$ of $\operatorname{PrP}(89-230)$ solution $(0.5 \mathrm{mg} / \mathrm{mL}$ of monomeric $\operatorname{PrP}(89-230)$ and $0.001 \mathrm{mg} / \mathrm{mL} \operatorname{PrP}(89-230)$ fibrils $)$ at a different time-points. The reaction kinetics were monitored by measuring ThT fluorescence intensity (ex. $440 \mathrm{~nm}$; em. $480 \mathrm{~nm}$ ) at $60{ }^{\circ} \mathrm{C}$ through a bottom of non-biding 96-well plate (Corning No. 3881, New York, United States) using ClarioStar Plus (BMG Labtech, Ortenberg, Germany) microplate reader. The measurements were performed every three minutes. The error bars are standard deviations estimated from 3 repeats. 
- $0.05 \mathrm{mg} / \mathrm{ml} \operatorname{PrP}(107-143)$ fibrils

$0.05 \mathrm{mg} / \mathrm{ml} \operatorname{PrP}(107-143)$ fibrils $+0.001 \mathrm{mg} / \mathrm{ml} \mathrm{PrP}(89-230)$ seed (added at $0 \mathrm{~min})$

$0.05 \mathrm{mg} / \mathrm{ml} \operatorname{PrP}(107-143)$ fibrils $+0.001 \mathrm{mg} / \mathrm{ml} \operatorname{PrP}(89-230)$ seed (added at $180 \mathrm{~min}$ )

a $0.05 \mathrm{mg} / \mathrm{ml} \mathrm{PrP}(107-143)$ fibrils $+0.001 \mathrm{mg} / \mathrm{ml} \operatorname{PrP}(89-230)$ seed (added at $360 \mathrm{~min}$ )

a

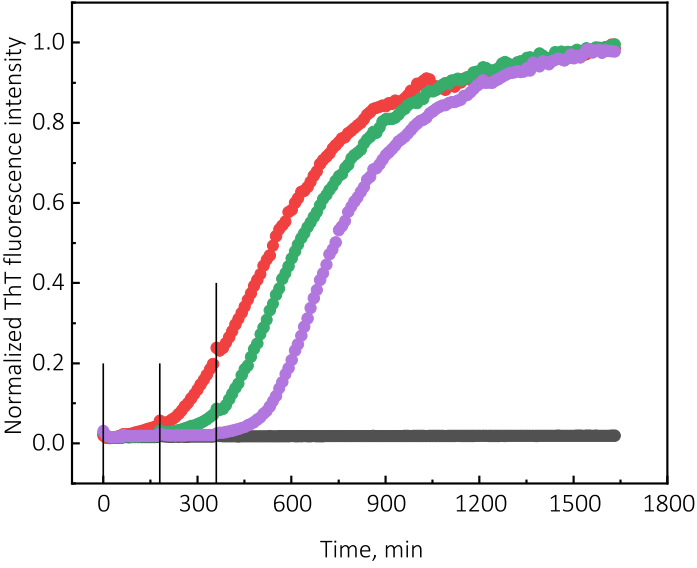

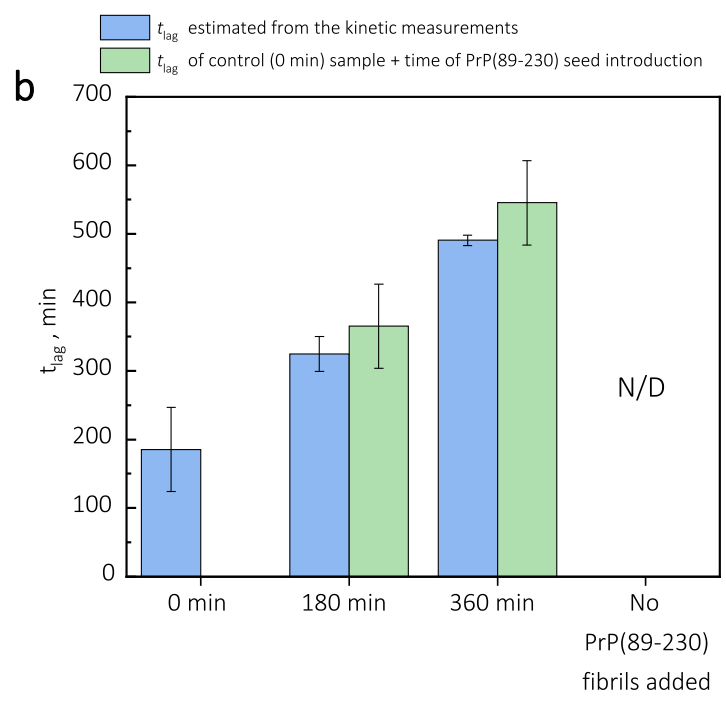

Figure A4. Average kinetic curves (a) and $t_{\text {lag }}$ values (b) of $\operatorname{PrP}(89-230)$ self-replication reaction performed with introduction of $\operatorname{PrP}(89-230)$ seed at different time-points of the reaction. Then, $10 \mu \mathrm{L}$ of $0.01 \mathrm{mg} / \mathrm{mL} \operatorname{PrP}(107-143)$ fibrils were added to $100 \mu \mathrm{L}$ of $\operatorname{PrP}(89-230)$ solution $(0.5 \mathrm{mg} / \mathrm{mL}$ of monomeric $\operatorname{PrP}(89-230)$ and $0.05 \mathrm{mg} / \mathrm{mL} \operatorname{PrP}(107-143)$ fibrils) at a different time-points. The reaction kinetics were monitored by measuring ThT fluorescence intensity (ex. $440 \mathrm{~nm}$; em. $480 \mathrm{~nm}$ ) at $60{ }^{\circ} \mathrm{C}$ through a bottom of non-biding 96-well plate (Corning No. 3881, New York, United States) using ClarioStar Plus (BMG Labtech, Ortenberg, Germany) microplate reader. The measurements were performed every ten minutes (the measurement frequency was reduced to avoid agitation-induced formation of $\operatorname{PrP}(89-230)$ aggregates, which in the presence of $\operatorname{PrP}(107-143)$ fibrils alone could lead to the false-positive results). The error bars are standard deviations estimated from 4 repeats. 

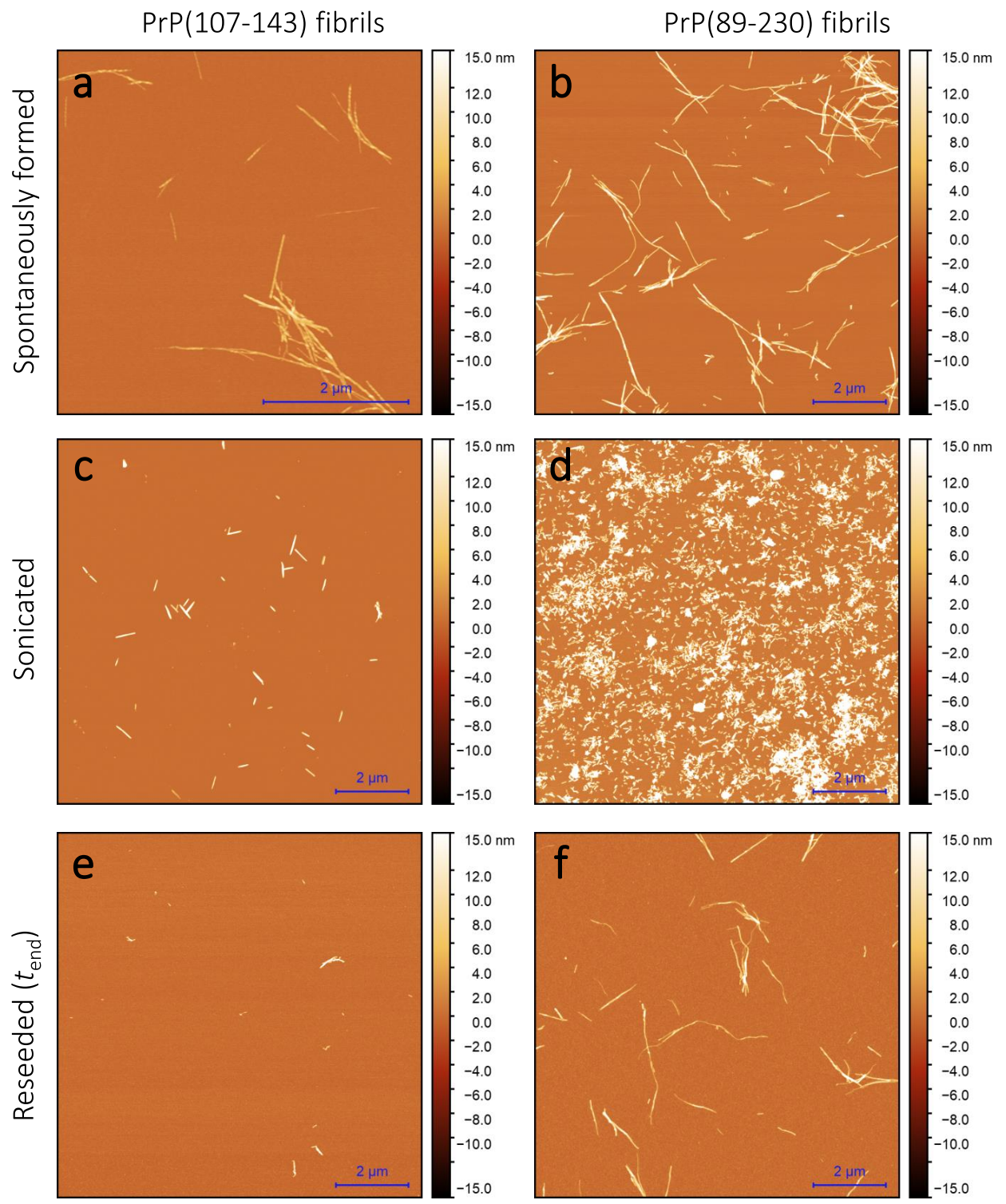

$10 \%$ of $\operatorname{PrP}(107-143)$ fibrils

$+1 \%$ of $\operatorname{PrP}(89-230)$ fibrils

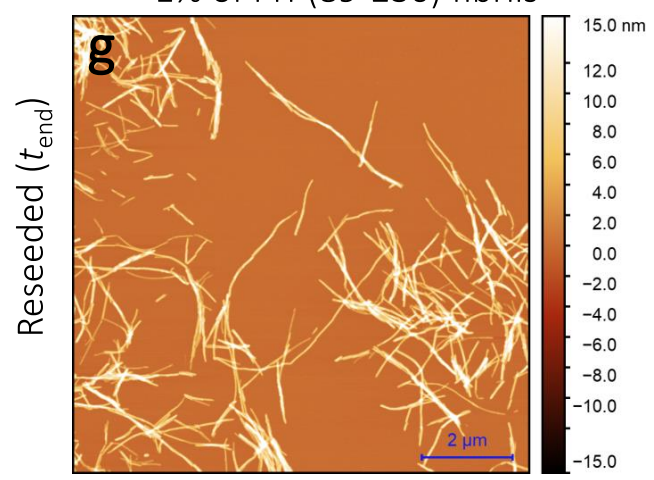

Figure A5. AFM images of $\operatorname{PrP}(107-143)$ and $\operatorname{PrP}(89-230)$ aggregates. Images of the spontaneously formed $\operatorname{PrP}(107-143)$ (a) and $\operatorname{PrP}(89-230)$ (b) aggregates. Images of sonicated $\operatorname{PrP}(107-143)$ (c) and $\operatorname{PrP}(89-230)$ (d) aggregates. Images of aggregates formed during $\operatorname{PrP}(107-143)$-fibril-induced (e) or $\operatorname{PrP}(89-230)$-seed-induced (f) aggregation reaction. Image of aggregates formed in the presence of both $\operatorname{PrP}(107-143)$-fibrils and $\operatorname{PrP}(89-230)$-seed (g). 


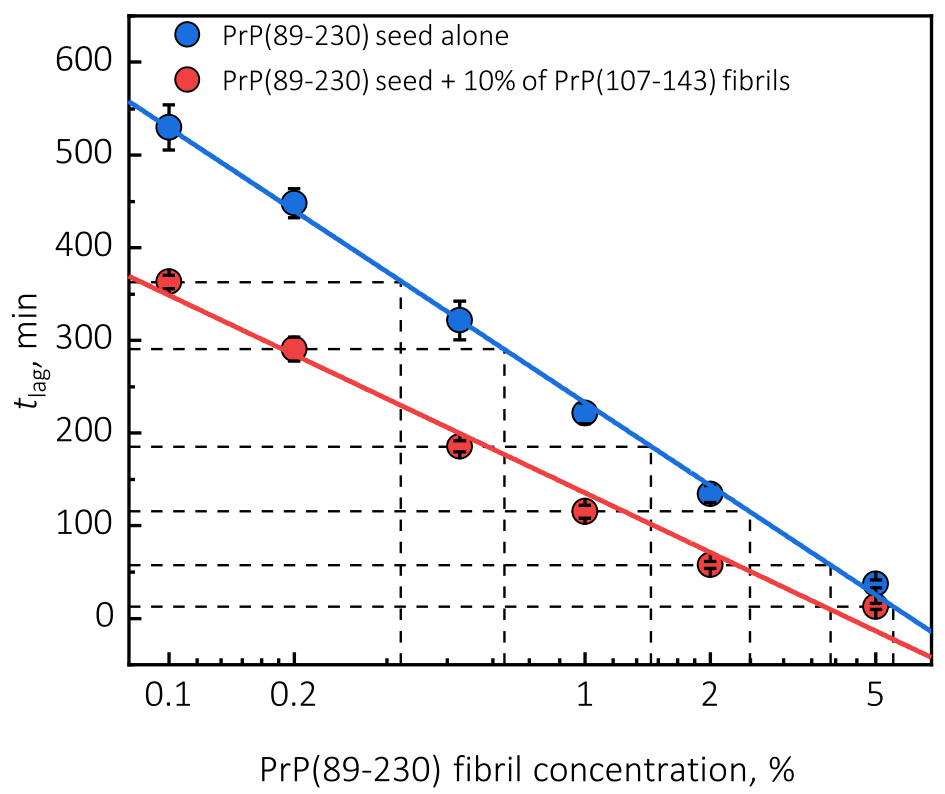

Figure A6. Comparison of $t_{\text {lag }}$ values of seed-induced aggregation reaction performed in the absence and presence of $10 \%$ of $\operatorname{PrP}(107-143)$ fibrils.

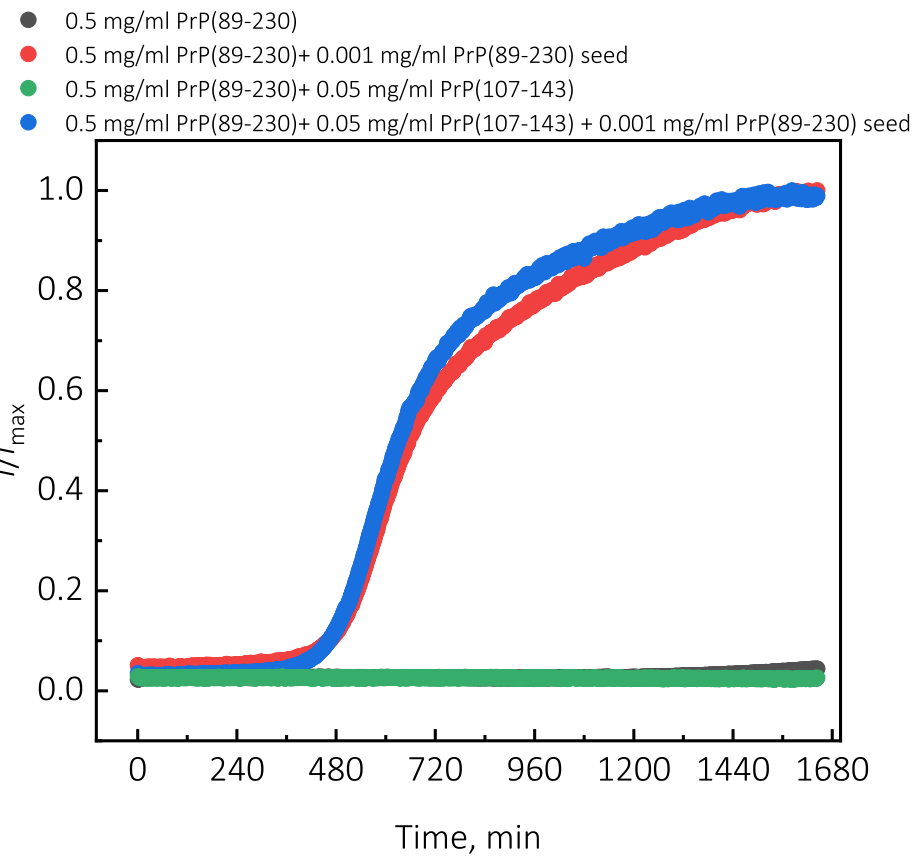

Figure A7. Representative curves of $\operatorname{PrP}(89-230)$ aggregation kinetics in the presence of monomeric $\operatorname{PrP}(107-143)$. For aggregation experiments, solutions of $0.5 \mathrm{mg} / \mathrm{mL}$ of monomeric $\operatorname{PrP}(89-230)$ in $0.5 \mathrm{M} \mathrm{GuHCl}, 50 \mathrm{mM}$ phosphate buffer ( $\mathrm{pH}$ 6), containing $50 \mu \mathrm{M}$ ThT were supplemented with either $0.001 \mathrm{mg} / \mathrm{mL}$ of $\operatorname{PrP}(89-230)$ seed, $0.05 \mathrm{mg} / \mathrm{mL}$ of $\operatorname{PrP}(107-143)$ monomers, or both $0.001 \mathrm{mg} / \mathrm{mL}$ of $\operatorname{PrP}(89-230)$ seed and $0.05 \mathrm{mg} / \mathrm{mL}$ of $\mathrm{PrP}(107-143)$ monomers. Aggregation reaction was performed under quiescent conditions at a $60{ }^{\circ} \mathrm{C}$ temperature. Aggregation kinetics were monitored by ThT fluorescence assay (excitation at $470 \mathrm{~nm}$, emission at $510 \mathrm{~nm}$ ) using Qiagen Rotor-Gene Q real-time analyzer. 


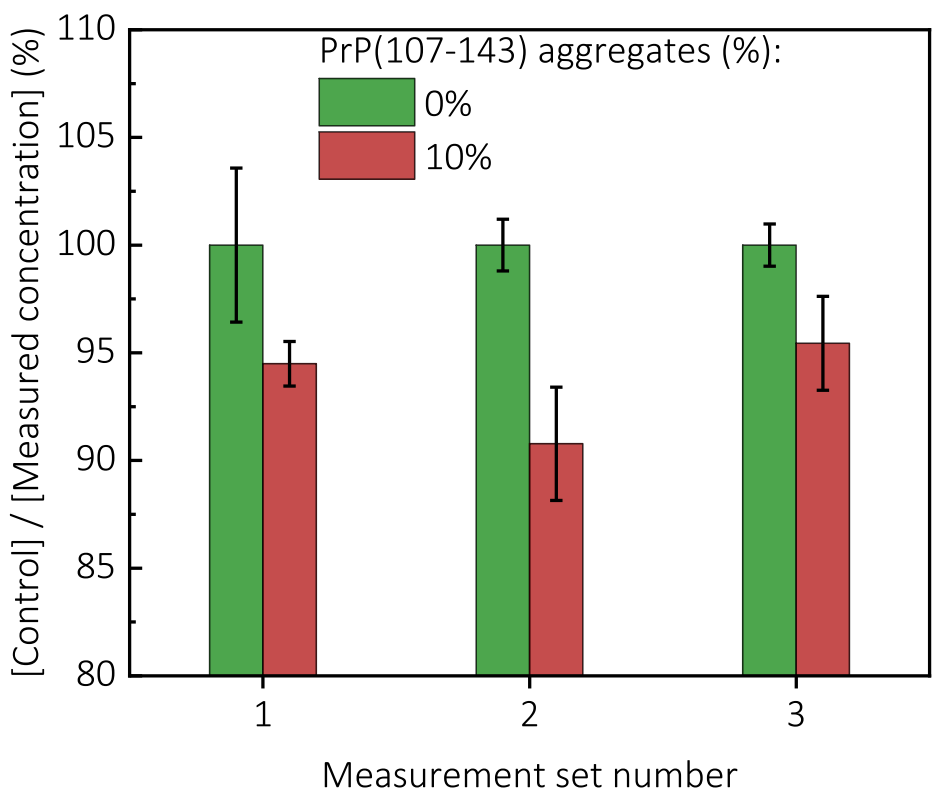

Figure A8. Measurements of $\operatorname{PrP}(89-230)$ concentration bound to the fibrils formed by $\operatorname{PrP}(107-143)$. For the measurements of monomeric $\operatorname{PrP}(89-230)$ binding to $\operatorname{PrP}(107-143)$ fibrils, $1 \mathrm{~mL}$ solutions of $0.5 \mathrm{mg} / \mathrm{mL}$ of monomeric $\operatorname{PrP}(89-230)$ in $0.5 \mathrm{M} \mathrm{GuHCl}, 50 \mathrm{mM}$ phosphate buffer (pH 6) supplemented with none or $0.05 \mathrm{mg} / \mathrm{mL}$ of $\operatorname{PrP}(107-143)$ fibrils were centrifuged at $12,000 \times g$ for $30 \mathrm{~min}$. Subsequently, concentration of monomeric $\operatorname{PrP}(89-230)$ remaining in the supernatant was determined by measuring UV-absorption at $280 \mathrm{~nm}$ using NanoDrop 2000 (Thermo Fisher Scientific). Error bars are standard deviations estimated from three repeats.
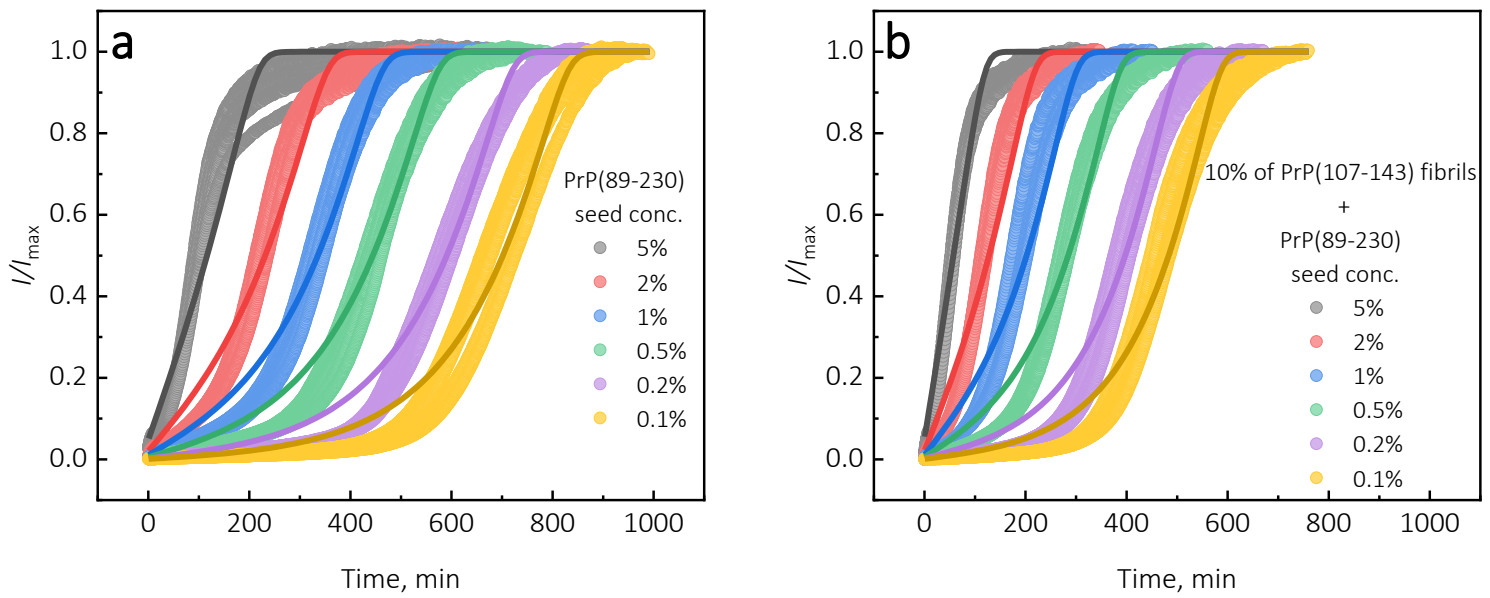

Figure A9. Kinetics of $\operatorname{PrP}(89-230)$-seed-induced aggregation reaction performed in the absence (a) or presence (b) of $\operatorname{PrP}(107-143)$ fibrils. Continuous lines denote the fit obtained by fitting "Saturated Elongation and Secondary Nucleation" model to the experimental data using the AmyloFit software [13].

\section{References}

1. Selkoe, D.J.; Hardy, J. The amyloid hypothesis of Alzheimer's disease at 25 years. EMBO Mol. Med. 2016, 8, 595-608. [CrossRef] [PubMed]

2. Poewe, W.; Seppi, K.; Tanner, C.M.; Halliday, G.M.; Brundin, P.; Volkmann, J.; Schrag, A.E.; Lang, A.E. Parkinson disease. Nat. Rev. Dis. Prim. 2017, 3, 1-21. [CrossRef] [PubMed]

3. Aguzzi, A.; Nuvolone, M.; Zhu, C. The immunobiology of prion diseases. Nat. Rev. Immunol. 2013, 13, 888-902. [CrossRef] [PubMed] 
4. Chiti, F.; Dobson, C.M. Protein misfolding, amyloid formation, and human disease: A summary of progress over the last decade. Annu. Rev. Biochem. 2017, 86, 27-68. [CrossRef]

5. Chuang, E.; Hori, A.M.; Hesketh, C.D.; Shorter, J. Amyloid assembly and disassembly. J. Cell Sci. 2018, 131. [CrossRef]

6. Knowles, T.P.J.; Vendruscolo, M.; Dobson, C.M. The amyloid state and its association with protein misfolding diseases. Nat. Rev. Mol. Cell Biol. 2014, 15, 384-396. [CrossRef]

7. Wisniewski, T.; Goñi, F. Immunotherapeutic approaches for Alzheimer's disease. Neuron 2015, 85, 1162-1176. [CrossRef]

8. Mehta, D.; Jackson, R.; Paul, G.; Shi, J.; Sabbagh, M. Why do trials for Alzheimer's disease drugs keep failing? A discontinued drug perspective for 2010-2015. Expert Opin. Investig. Drugs 2017, 26, 735-739. [CrossRef]

9. Castellani, R.J.; Plascencia-Villa, G.; Perry, G. The amyloid cascade and Alzheimer's disease therapeutics: Theory versus observation. Lab. Investig. 2019, 99, 958-970. [CrossRef]

10. Sneideris, T.; Sakalauskas, A.; Sternke-Hoffmann, R.; Peduzzo, A.; Ziaunys, M.; Buell, A.K.; Smirnovas, V. The environment is a key factor in determining the anti-amyloid efficacy of EGCG. Biomolecules 2019, 9, 855. [CrossRef]

11. Marín-Moreno, A.; Fernández-Borges, N.; Espinosa, J.C.; Andréoletti, O.; Torres, J.M. Transmission and replication of prions. Prog. Mol. Biol. Transl. Sci. 2017, 150, 181-201. [PubMed]

12. Meisl, G.; Yang, X.; Hellstrand, E.; Frohm, B.; Kirkegaard, J.B.; Cohen, S.I.a.; Dobson, C.M.; Linse, S.; Knowles, T.P.J. Differences in nucleation behavior underlie the contrasting aggregation kinetics of the A $\beta 40$ and A 342 peptides. Proc. Natl. Acad. Sci. USA 2014, 111, 9384-9389. [PubMed]

13. Meisl, G.; Kirkegaard, J.B.; Arosio, P.; Michaels, T.C.T.; Vendruscolo, M.; Dobson, C.M.; Linse, S.; Knowles, T.P.J. Molecular mechanisms of protein aggregation from global fitting of kinetic models. Nat. Protoc. 2016, 11, 252-272. [CrossRef] [PubMed]

14. Michaels, T.C.T.; Šarić, A.; Habchi, J.; Chia, S.; Meisl, G.; Vendruscolo, M.; Dobson, C.M.; Knowles, T.P.J. Chemical kinetics for bridging molecular mechanisms and macroscopic measurements of amyloid fibril formation. Annu. Rev. Phys. Chem. 2018, 69, 273-298. [CrossRef]

15. Knowles, T.P.J.; Waudby, C.A.; Devlin, G.L.; Cohen, S.I.A.; Aguzzi, A.; Vendruscolo, M.; Terentjev, E.M.; Welland, M.E.; Dobson, C.M. An analytical solution to the kinetics of breakable filament assembly. Science 2009, 326, 1533-1537. [CrossRef]

16. Makarava, N.; Ostapchenko, V.G.; Savtchenko, R.; Baskakov, I.V. Conformational switching within individual amyloid fibrils. J. Biol. Chem. 2009, 284, 14386-14395. [CrossRef]

17. Baskakov, I.V. Switching in amyloid structure within individual fibrils: Implication for strain adaptation, species barrier and strain classification. FEBS Lett. 2009, 583, 2618-2622. [CrossRef]

18. Sneideris, T.; Milto, K.; Smirnovas, V. Polymorphism of amyloid-like fibrils can be defined by the concentration of seeds. Peer] 2015, 3, e1207. [CrossRef]

19. Brännström, K.; Islam, T.; Gharibyan, A.L.; Iakovleva, I.; Nilsson, L.; Lee, C.C.; Sandblad, L.; Pamrén, A.; Olofsson, A. The properties of amyloid- $\beta$ fibrils are determined by their path of formation. J. Mol. Biol. 2018, 430, 1940-1949.

20. Sakalauskas, A.; Ziaunys, M.; Smirnovas, V. Concentration-dependent polymorphism of insulin amyloid fibrils. PeerJ 2019, 2019. [CrossRef]

21. Peduzzo, A.; Linse, S.; Buell, A.K. The properties of $\alpha$-synuclein secondary nuclei are dominated by the solution conditions eather than the seed fibril strain. ACS Chem. Neurosci. 2020, 11, 909-918. [CrossRef] [PubMed]

22. Cobb, N.J.; Surewicz, W.K. Prion strains under the magnifying glass. Nat. Struct. Mol. Biol. 2007, 14, 882-884. [CrossRef] [PubMed]

23. Lu, X.; Wintrode, P.L.; Surewicz, W.K. $\beta$-sheet Core of Human prion protein amyloid fibrils as determined By hydrogen/deuterium exchange. Proc. Natl. Acad. Sci. USA 2007, 104, 1510-1515. [CrossRef] [PubMed]

24. Tycko, R.; Savtchenko, R.; Ostapchenko, V.G.; Makarava, N.; Baskakov, I.V. The $\alpha$-helical C-Terminal domain of full-length recombinant PrP converts to an In-register parallel $\beta$-sheet structure in PrP fibrils: Evidence from solid state nuclear magnetic resonance. Biochemistry 2010, 49, 9488-9497. [CrossRef] 
25. Wang, L.Q.; Zhao, K.; Yuan, H.Y.; Wang, Q.; Guan, Z.; Tao, J.; Li, X.N.; Sun, Y.; Yi, C.W.; Chen, J. Cryo-EM structure of an amyloid fibril formed by full-length human prion protein. Nat. Struct. Mol. Biol. 2020, 27, 598-602. [CrossRef]

26. Smirnovas, V.; Baron, G.S.; Offerdahl, D.K.; Raymond, G.J.; Caughey, B.; Surewicz, W.K. Structural organization of brain-derived mammalian prions examined by hydrogen-deuterium exchange. Nat. Struct. Mol. Biol. 2011, 18, 504-506. [CrossRef]

27. Choi, J.K.; Cali, I.; Surewicz, K.; Kong, Q.; Gambetti, P.; Surewicz, W.K. Amyloid fibrils from the N-terminal prion protein fragment are infectious. Proc. Natl. Acad. Sci. USA 2016, 113, 13851-13856. [CrossRef]

28. Helmus, J.J.; Surewicz, K.; Surewicz, W.K.; Jaroniec, C.P. Conformational flexibility of Y145Stop human prion protein amyloid fibrils probed by solid-state Nuclear magnetic resonance spectroscopy. J. Am. Chem. Soc. 2010, 132, 2393-2403. [CrossRef]

29. Chatterjee, B.; Lee, C.Y.; Lin, C.; Chen, E.H.L.; Huang, C.L.; Yang, C.C.; Chen, R.P.Y. Amyloid core formed of full-length recombinant mouse prion protein involves sequence 127-143 but not sequence 107-126. PLoS ONE 2013, 8, e67967. [CrossRef]

30. Morinaga, A.; Hasegawa, K.; Nomura, R.; Ookoshi, T.; Ozawa, D.; Goto, Y.; Yamada, M.; Naiki, H. Critical role of interfaces and agitation on the nucleation of $\mathrm{A} \beta$ amyloid fibrils at low concentrations of $\mathrm{A} \beta$ monomers. Biochim. Biophys. Acta (BBA) Proteins Proteom. 2010, 1804, 986-995. [CrossRef]

31. Linse, S. Mechanism of amyloid protein aggregation and the role of inhibitors. Pure Appl. Chem. 2019, 91, 211-229. [CrossRef]

32. Sasahara, K.; Yagi, H.; Sakai, M.; Naiki, H.; Goto, Y. Amyloid nucleation Triggered by agitation of $\beta 2$-microglobulin under acidic and neutral $\mathrm{pH}$ conditions. Biochemistry 2008, 47, 2650-2660.

33. Buell, A.K. The Nucleation of Protein Aggregates-From Crystals to Amyloid Fibrils, 1st ed.; Elsevier Inc.: Amsterdam, The Netherlands, 2017; Volume 329, pp. 187-226.

34. Milto, K.; Michailova, K.; Smirnovas, V. Elongation of mouse prion protein amyloid-like fibrils: Effect of temperature and denaturant concentration. PLoS ONE 2014, 9, e94469. [CrossRef] [PubMed]

35. Arosio, P.; Knowles, T.P.; Linse, S. On the lag phase in amyloid fibril formation. Phys. Chem. Chem. Phys. 2015, 17, 7606-7618. [CrossRef] [PubMed]

36. Krapivsky, P.L.; Redner, S.; Ben-Naim, E. A Kinetic View of Statistical Physics; Cambridge University Press: Cambridge, UK, 2010.

37. Šaric, A.; Buell, A.K.; Meisl, G.; Michaels, T.C.; Dobson, C.M.; Linse, S.; Knowles, T.P.; Frenkel, D. Physical determinants of the self-replication of protein fibrils. Nat. Phys. 2016, 12, 874-880. [CrossRef] [PubMed]

38. Ziaunys, M.; Sneideris, T.; Smirnovas, V. Formation of distinct prion protein amyloid fibrils under identical experimental conditions. Sci. Rep. 2020, 10, 4572. [CrossRef]

39. Ruggeri, F.S.; Vieweg, S.; Cendrowska, U.; Longo, G.; Chiki, A.; Lashuel, H.A.; Dietler, G. Nanoscale studies link amyloid maturity with polyglutamine diseases onset. Sci. Rep. 2016, 6, 31155. [CrossRef]

40. Schägger, H. Tricine-SDS-PAGE. Nat. Protoc. 2006, 1, 16-22. [CrossRef]

(C) 2020 by the authors. Licensee MDPI, Basel, Switzerland. This article is an open access article distributed under the terms and conditions of the Creative Commons Attribution (CC BY) license (http:/ / creativecommons.org/licenses/by/4.0/). 